\title{
Inheritance of Heat Tolerance during Reproductive Development in Snap Bean (Phaseolus vulgaris L.)
}

\author{
Katy M. Rainey and Phillip D. Griffiths ${ }^{1}$ \\ Department of Horticultural Sciences, Cornell University NYSAES, Geneva, NY 14456
}

\begin{abstract}
AdDitional INDEX WORDS. abiotic stress, abscission, breeding, common bean, epistasis, generation means analysis, heterosis, high temperature

Aвstract. The genetic basis for heat tolerance during reproductive development in snap bean was investigated in a heat-tolerant $x$ heat-sensitive common bean cross. Parental, $F_{1}, F_{2}$, and backcross generations of a cross between the heat-tolerant snap bean breeding line 'Cornell 503' and the heat-sensitive wax bean cultivar Majestic were grown in a high-temperature controlled environment $\left(32{ }^{\circ} \mathrm{C}\right.$ day/28 ${ }^{\circ} \mathrm{C}$ night $)$, initiated prior to anthesis and continued through plant senescence. During flowering, individual plants of all generations were visually rated and scored for extent of abscission of reproductive organs. The distribution of abscission scores in segregating generations ( $F_{2}$ and backcrosses) indicated that a high rate of abscission in response to heat stress was controlled by a single recessive gene from 'Majestic'. Abscission of reproductive organs is the primary determinant of yield under heat stress in many annual grain legumes; this is the first known report of single gene control of this reaction in common bean or similar legumes. Generation means analysis indicated that genetic variation among generations for pod number under heat stress was best explained by a six-parameter model that includes nonallelic interaction terms, perhaps the result of the hypothetical abscission gene interacting with other genes for pod number in the populations. A simple additive/dominance model accounted for genetic variance for seeds per pod. Dominance $[h]$ and epistatic dominance $\times$ dominance $[l]$ genetic parameters for yield components under high temperatures were the largest in magnitude. Results suggest 'Cornell 503' can improve heat tolerance in sensitive cultivars, and heat tolerance in common bean may be influenced by major genes.
\end{abstract}

High temperatures $\left(>30^{\circ} \mathrm{C}\right.$ day and/or $>20^{\circ} \mathrm{C}$ night) during reproductive development reduce yields in common bean. High temperature also limits geographic range of cultivation and is the primary reason snap beans are not planted in summer months in the southeastern United States (Silbernagel, 1986), or that common beans are planted only in cooler seasons in tropical growing areas (Porch, 2001). Due to abscission of buds, flowers, and pods, brief heat waves in North American growing areas cause split sets in snap bean fields (Myers and Baggett, 1999; Silbernagel, 1986), characterized by differences in size of the pods which set before and after a heat wave. High temperatures around anthesis also reduce seed set, perhaps due to impaired pollen tube growth and fertilization (Gross and Kigel, 1994), resulting in deformed pods that reduce product quality in snap bean.

Abscission of reproductive organs under high-temperature stress can be the primary determinant of pod set in common bean (Konsens et al., 1991), and other annual legumes, including peanut (Arachis hypogeae L.; Prasad et al., 1999), cowpea [Vigna unguiculata (L.) Walp.; Craufurd et al., 1998], and pea (Pisum sativum L.; Guilioni et al., 1997). The highest rates of abscission occur when heat stress is experienced before anthesis in common bean (Konsens et al., 1991; Monterroso and Wien, 1990), as in peanut (Prasad et al., 1999) and cowpea (Craufurd et al., 1998). Flowers are the most likely reproductive organs to abscise, followed by young pods ( $<2 \mathrm{~cm}$ long), and then buds (Konsens et al., 1991; Monterroso and Wien, 1990). Abscission of reproductive organs also occurs under optimal conditions in common bean and other grain legumes, though the mechanisms inducing abscission under optimal conditions may be different from those under heat stress (Konsens et al., 1991).

Possible mechanisms influencing abscission of reproductive organs (RO) under heat stress in common bean include reduced

Received for publication 16 Sept. 2005. Accepted for publication 7 Mar. 2005. 'To whom reprints should be addressed. E-mail address: pdg8@cornell.edu photoassimilate availability, disruption of source-sink relations, decrease of metabolic activity of reproductive organs, quantity of certain plant hormones, and failure of fertilization and embryo development. However, the physiological association between these traits and their influence on abscission of RO under heat stress in common bean and other grain legumes remains unclear. Limitation of carbohydrate supply has been implicated in abscission of RO under a range of conditions in many crop species, including pepper (Capsicum anuum L.; Aloni et al., 1996; Marcelis et al., 2004) and grape (Vitis vinifera L.; Lebon et al., 2004). However, Ahmed et al. (1993) demonstrated that increasing atmospheric carbon dioxide concentration in high-temperature conditions increased carbohydrate levels but did not improve heat tolerance in cowpea. Implicating plant hormones in the control of abscission under heat stress, Ofir et al. (1993) examined common bean cultivars differing in heat tolerance, and observed those cultivars with higher tolerance of pod set to high temperatures had smaller relative reductions in indol-3yl-acetic acid (IAA) exported to agar. Aloni et al. (1996) associated abscission of individual RO under heat stress with decreases in metabolic activity of the RO. There is evidence that plant hormones affect number of sinks and the metabolic activity of sinks on a plant (Kuiper, 1993), a possible explanation of the results of Ofir et al. (1993) and Aloni et al. (1996). High temperatures may have a direct damaging effect on reproductive development. Mutters and Hall (1992) observed that high night temperatures occurring only during the last $6 \mathrm{~h}$ of a 12-h night period reduces pollen viability and pod set in cowpeas, and hypothesized that a heat-sensitive process in pollen development is under circadian control. This may account for the interaction between photoperiod and heat stress in cowpea, as both photoperiod sensitivity and circadian rhythms are mediated by phytochrome (Hall, 2004). The expression of heat-shock proteins (HSPs) makes plants more tolerant to abrupt and extreme increases in temperatures (Vierling, 1991). However, heat stress during reproductive development in grain legumes occurs under moderately elevated temperatures, below tempera- 
tures that cause physiological heat stress. Heat-shock proteins were not associated with relative heat acclimation potential in six common beans (Li and Udomprasert, 1993). Cowpea lines differing in reproductive heat tolerance produced the same set of low molecular weight HSPs in their leaves when subjected to moderately elevated temperatures (Hall, 2004), suggesting HSPs were not conditioning heat tolerance.

This study investigates genetic control of heat tolerance in a tolerant snap bean ('Cornell 503') $\times$ sensitive wax bean ('Majestic') cross (Rainey and Griffiths, 2005a). Though the parents of the cross are in separate market classes they should not be genetically divergent. Two genes ( $y$ and $\mathrm{Arg}$ ) are responsible for the wax bean yellow-podded phenotype (Currence, 1931; Lamprecht, 1947), and comparison of molecular diversity in snap bean based on RAPD markers indicated wax beans are dispersed genetically among snap beans (Cunha et al., 2004). In prior work the wax bean cultivar Carson (Syngenta Seeds, Golden Valley, Minn.) was identified as heat tolerant, in contrast to the heat-sensitive 'Majestic', evidence that tolerance or sensitivity to high temperatures during reproductive development is not linked to the wax bean genotype (Rainey and Griffiths, 2005a). There is evidence that snap bean has a broad genetic base (Haley et al., 1994; Skroch and Nienhuis, 1995), but modern germplasm has uniform morphological and developmental characteristics, such as upright growth habit, early maturity, small seeds, low-fiber pods, and a concentrated pod set. For commercial production purposes snap beans are harvested in a single destructive harvest. To maximize yields, snap beans have been selected to have near-simultaneous bloom, leading to concentrated pod set and pod-filling (Myers and Baggett, 1999). These uniform morphological and developmental characteristics facilitate studies of heat tolerance in snap bean because plants in a controlled-environment study experience heat stress at a similar stage of development. Additionally, most modern snap bean germplasm is determinate, which in combination with the short flowering time prevents "escapes," or plants which avoid heat stress by delaying flowering or pod set until the stress passes.

The objectives of this study were to 1) evaluate the inheritance of yield components in snap bean under heat stress in six populations generated from a single cross, and 2) study the genetic control of abscission of reproductive organs under heat stress.

\section{Materials and Methods}

Plant materials. 'Cornell 503' and 'Majestic' were used to generate $\mathrm{F}_{1}, \mathrm{~F}_{2}, \mathrm{BC}_{1} \mathrm{P}_{1}\left(\mathrm{~F}_{1} \times\right.$ 'Majestic' $)$, and $\mathrm{BC}_{1} \mathrm{P}_{2}\left(\mathrm{~F}_{1} \times\right.$ 'Cornell 503') populations, with reciprocals. 'Cornell 503' is heat-tolerant snap bean inbred breeding line (Cornell Univ., Geneva, N.Y.) and 'Majestic' is a heat-sensitive wax bean cultivar (Rogers Seed, Boise, Idaho). Both have a type I determinate upright bush growth habit.

The high-temperature stress response of both parents was determined in a previous study (Rainey and Griffiths, 2005a), in which 'Majestic' exhibited a $29 \%$ decrease in pod number and an $9 \%$ decrease in seeds per pod in a range from two nonstress treatments $\left(24{ }^{\circ} \mathrm{C}\right.$ day $/ 21^{\circ} \mathrm{C}$ night and $\left.27{ }^{\circ} \mathrm{C} / 24{ }^{\circ} \mathrm{C}\right)$ to a moderate heat-stress treatment $\left(30^{\circ} \mathrm{C} / 27{ }^{\circ} \mathrm{C}\right)$, and $100 \%$ yield loss under severe heat stress conditions of $33{ }^{\circ} \mathrm{C} / 30{ }^{\circ} \mathrm{C}$. It was observed in that study that yield loss under high temperatures in 'Majestic' is due to abscission of reproductive organs beginning at bud primordial stage through anthesis, and abscission of many flowers 1-2 d post-anthesis. 'Cornell 503' displayed relatively higher heat tolerance under the same conditions with a $17 \%$ increase in pod number and a $13 \%$ decrease in seeds per pod in the $30{ }^{\circ} \mathrm{C} / 27^{\circ} \mathrm{C}$ treatment, and $21 \%$ decrease in pod number and a $14 \%$ decrease in seeds per pod in the $33{ }^{\circ} \mathrm{C} / 30{ }^{\circ} \mathrm{C}$ treatment. 'Cornell 503' produces a short flush of many flowers, most of which develop into pods.

Experimental Design. Four replications divided a $90-\mathrm{m}^{2}$ greenhouse into quadrants. Forty plants of each of the parental and $F_{1}$ generations, 400 plants of the $F_{2}$ generation, and 80 plants of each of the backcross generations were divided equally between the four replications. Plots of five plants of the same generation were randomized in each replication. Reciprocals of each generation were included in equal numbers, but data collection and analysis did not control for this effect, based on results from a previous diallel analysis indicating reciprocal effects were not significant for heat tolerance in related material (Rainey and Griffiths, 2005b).

Seed of the six generations were sown 9 Mar. 2004 in 14.6 $\times$ 14.6-cm square pots filled with "Cornell mix" (Boodley and Sheldrake, 1972) in the greenhouse. The greenhouse was set for a 14-h photoperiod with supplemental lighting provided by $1000-\mathrm{W}$ metal halide bulbs (SunSystem III; Sunlight Supply, Vancouver, Wash.) at a rate of $300 \mu \mathrm{mol} \cdot \mathrm{m}^{-2} \cdot \mathrm{s}^{-1}$ of photosynthetically active radiation at bench level. Greenhouse temperatures were set at $24{ }^{\circ} \mathrm{C}$ day $/ 21{ }^{\circ} \mathrm{C}$ night for germination and development of seedlings. Temperatures were raised to $32{ }^{\circ} \mathrm{C} / 28^{\circ} \mathrm{C}$ on $22 \mathrm{Mar}$. 2004, 9 d prior to earliest anthesis. A high night temperature was used because high night temperatures are more detrimental to yield in common bean than high day temperatures (Konsens et al., 1991). Heat treatment ceased when plants had begun to senesce on 29 Apr. 2004. Plants were irrigated as needed and fertilized equally.

After plants had dried down, all pods were harvested from individual plants. Pod and seed counts, and seed weight (to 0.01 g) were recorded separately for each plant in the experiment. Pins were defined as pods not possessing any seeds and were counted separately from pods (data not shown).

Abscission was measured by visually rating the extent of abscission of reproductive organs (RO) abscising from individual plants on 19 Apr. 2004, $\approx 17 \mathrm{~d}$ after anthesis. RO abscised at a range of developmental stages, from small buds $(\approx 7 \mathrm{~d}$ before anthesis) to small pins $(\approx 3 \mathrm{~d}$ after anthesis). Individual plants were rated on a scale of $1-5$, with $1=$ abscission of $\approx 100 \%$ of $\mathrm{RO}, 2=$ abscission of mean of $75 \% \mathrm{RO}, 3=$ abscission of mean of $50 \%$ of RO, $4=$ abscission of mean of $25 \%$ of RO, and $5=$ virtually no abscission of RO. In biological systems absolute vales such as zero abscission or total abscission rarely occur. Even under optimal conditions some abscission will always occur on individual plants in common bean. However, individuals with a "5" rating set pods from most first opened flowers, without production and subsequent abscission of many flowers. A rating of " 1 " represented that essentially no flower set pods.

STATISTICAL ANALYSIS. A joint-scaling test was performed for the yield components pod number and seeds per pod using parental, $\mathrm{F}_{1}, \mathrm{~F}_{2}, \mathrm{BC}_{1} \mathrm{P}_{1}$, and $\mathrm{BC}_{1} \mathrm{P}_{2}$ generation means and variances to provide estimates for the estimated mean [m], additive effects $[d]$, and dominance effects $[h]$. Goodness-of-fit of the three-parameter model to the observed data was evaluated by assuming the sum of the squared deviations follows a chi-square $\left(\chi^{2}\right)$ distribution with three degrees of freedom. Lack of fit implies the existence of non-additive gene effects other than dominance (Cavalli, 1952). When the three parameter model did not show a good fit for pod number, a six-parameter scaling test to determine the adequacy 
of a digenic epistatic model was performed (Mather and Jinks, 1982). This test requires a minimum of six family means and estimates $[\mathrm{m}],[d]$, and $[h]$, and three nonallelic (epistatic) interaction parameters: additive $\times$ additive $[i]$, additive $\times$ dominance $[j]$, dominance $\times$ dominance $[l]$. The calculations were completed using the JNTSCALE software (Ng, 1990), which also provided estimates of broad-sense heritability according to the following formula from Allard (1960): $\mathrm{H}=\sigma_{\mathrm{a}}^{2} / \sigma_{\mathrm{A}}^{2}$. The three- and sixparameter scaling tests are described in detail in Mather and Jinks (1982). Significance of the genetic parameters was determined with one-sample $t$ tests where, for example, $t=[d] / \sigma_{[d]}^{2}$ and degrees of freedom $=$ (number of generations used to estimate $[d]) \times($ number of replicates -1 ), and so forth for each parameter. The goodness-of-fit of the observed segregation of abscission score to expected segregation ratios under the hypothesis of a single Mendelian gene with dominant or recessive alleles was tested using the $\chi^{2}$ statistic with 2 df. Correlations among yield components and abscission score were calculated using Pearson product-moment correlations (SAS, 1997).

\section{Results}

Generation means for abscission score, pod number, and seeds per pod are presented in Table 1. Significant differences were detected among generations for the traits measured. The effect of replication was significant $(P<0.05)$ for pod number only. As expected, abscission scores, pod number, and seed number means were lower for 'Majestic' $\left(\mathrm{P}_{1}\right)$ than for 'Cornell 503' $\left(\mathrm{P}_{2}\right)$. Means for pod number and seeds per pod were significantly higher in the $\mathrm{F}_{1}$ generation compared to 'Cornell 503' (Table 1), with large positive high-parent heterosis (Fehr, 1987), suggesting nonallelic interaction. High-parent heterosis for pod number was also significant in the $\mathrm{BC}_{1} \mathrm{P}_{2}$ generation. Individual plants of 'Majestic' were larger overall compared to 'Cornell 503'. The $\mathrm{F}_{1}$ and $\mathrm{BC}_{1} \mathrm{P}_{2}$ plants were subsequently larger than 'Cornell 503', which may have contributed to the heterosis seen in these generations, as larger plants may have greater yield potential. For both pod number and seeds per pod, the $\mathrm{F}_{2}$ and $\mathrm{P}_{2}$ generation means were statistically equivalent. $\mathrm{BC}_{1} \mathrm{P}_{1}$ means were significantly different from both parents, and may be explained by segregation of a gene affecting pod set (see below), rather than additive effects. Pod number, seeds per pod, and abscission score were all highly correlated with $(P \leq 0.0001)$ with one another (data not shown).

The distribution of abscission scores in segregating generations (Fig. 1) suggested the hypothesis that a high rate of abscission in response to heat stress was controlled by a single recessive gene from 'Majestic,' and that this allele was segregating in the

Table 1. Generation means $( \pm \mathrm{SE})$ for parental, $\mathrm{F}_{1}$, and three segregating generations from the cross 'Majestic' $\times$ 'Cornell 503' when plants were grown under high-temperature stress $\left(32{ }^{\circ} \mathrm{C}\right.$ day $/ 28^{\circ} \mathrm{C}$ night) in a controlled environment.

\begin{tabular}{|c|c|c|c|c|c|c|c|}
\hline Generation & $\mathrm{n}^{\mathrm{z}}$ & \multicolumn{2}{|c|}{ Abscission score } & \multicolumn{2}{|c|}{ Pods (no.) } & \multicolumn{2}{|c|}{ Seeds (no./pod) } \\
\hline$\overline{\mathrm{P}_{1} \text { ('Majestic’) }}$ & 37 & $1.41 \mathrm{dy}$ & \pm 0.25 & $0.57 \mathrm{~d}$ & \pm 2.08 & $1.17 \mathrm{~d}$ & \pm 0.18 \\
\hline $\mathrm{P}_{2}$ ('Cornell 503') & 40 & $3.58 \mathrm{a}$ & \pm 0.30 & $10.65 \mathrm{~b}$ & \pm 2.43 & $2.92 \mathrm{~b}$ & \pm 0.66 \\
\hline $\mathrm{F}_{1}$ & 39 & $3.15 \mathrm{~b}$ & \pm 0.13 & $13.33 \mathrm{a}$ & \pm 2.73 & $3.55 \mathrm{a}$ & \pm 0.62 \\
\hline $\mathrm{F}_{2}$ & 387 & $3.12 \mathrm{~b}$ & \pm 1.06 & $10.35 \mathrm{~b}$ & \pm 4.30 & $2.97 \mathrm{~b}$ & \pm 0.99 \\
\hline $\mathrm{BC}_{1} \mathrm{P}_{1}$ & 70 & $2.31 \mathrm{c}$ & \pm 1.04 & $4.81 \mathrm{c}$ & \pm 4.57 & $1.97 \mathrm{c}$ & \pm 1.53 \\
\hline $\mathrm{BC}_{1} \mathrm{P}_{2}$ & 78 & $3.42 \mathrm{ab}$ & \pm 0.30 & $12.72 \mathrm{a}$ & \pm 4.57 & $3.33 \mathrm{ab}$ & \pm 0.68 \\
\hline HP heterosis ${ }^{x}$ & & --- & & $25.2 \%$ & & $17.7 \%$ & \\
\hline
\end{tabular}

${ }^{\mathrm{z}} \mathrm{n}=$ number of observations per generation.

yMeans within a column not followed by the same letters are significantly different $(P \leq 0.05)$ according to Duncan's multiple range test.

${ }^{x}$ High-parent heterosis $(\%)=\left(\mathrm{F}_{1}-\mathrm{HP}\right) / \mathrm{HP} \times 100$, where $\mathrm{HP}=$ performance of the best parent.
$\mathrm{BC}_{1} \mathrm{P}_{1}$ and $\mathrm{F}_{2}$ generations. Observed segregation ratios in the $\mathrm{F}_{2}$, $\mathrm{BC}_{1} \mathrm{P}_{1}$, and $\mathrm{BC}_{1} \mathrm{P}_{2}$ generations were not significantly different from expected segregation ratios under the hypothesis of a single recessive gene conditioning the high-abscission phenotype (Table 2 ). Additionally, abscission scores of " 1 " or " 2 ," indicating high abscission of reproductive organs, were absent in the $F_{1}$ as all individuals possessed the dominant allele from 'Cornell 503'. The $\mathrm{F}_{1}$ generation would be heterozygous for the alleles of the hypothetical abscission gene, and the majority of individuals in the $\mathrm{F}_{1}$ generation were scored for abscission as a " 3 ." This suggests the abscission allele from 'Cornell 503 ' may be incompletely dominant. For calculation of segregation ratios, scores of " 1 " and " 2 " were grouped into a class representing the heat-sensitive, high-abscission, 'Majestic' phenotype. In the histograms in Fig. 1 , scores of " 4 " and " 5 " were grouped into a class because so few plants received a " 5 " score.

Histograms for pod number and seeds per pod (Fig. 2) are included for illustrative purposes, and the generation means analyses for these traits (see below) were calculated for individual plants in the study. Distributions in the $\mathrm{BC}_{1} \mathrm{P}_{1}$ and $\mathrm{BC}_{1} \mathrm{P}_{2}$ generations were skewed towards the recurrent parent. The $\mathrm{BC}_{1} \mathrm{P}_{1}$ displayed bimodal distributions for pod number and seeds per pod due to $1: 1$ segregation of the recessive abscission allele from 'Majestic' and the dominant abscission allele from 'Cornell 503'. The distribution of pod number in the $\mathrm{BC}_{1} \mathrm{P}_{2}$ is similar to 'Cornell 503' due to dominance of the allele from that parent. Pod number in the $\mathrm{F}_{2}$ does not completely reflect action of the recessive abscission allele, as some plants abscised a large percentage of RO but also displayed moderate to high pod set. As abscission scores were based on percentage of $\mathrm{RO}$ abscising, some $\mathrm{F}_{2}$ plants producing many RO received an abscission score of " 2 " while maintaining high pod set, a reflection of the total number of RO produced. Differences in plant size between the parents may explain this observation. In $\mathrm{F}_{2}$ individuals with a high abscission/high pod set phenotype, interaction of factors from both parents resulted in large plants that produced many reproductive organs. This effect was also evident in some individual 'Majestic' plants that set a one to four pods with high seeds per pod, contributing to high variance for seeds per pod for 'Majestic.' Additionally, the $\mathrm{F}_{2}$ histogram for seeds per pod showed a quantitative distribution, which when compared to the $\mathrm{F}_{1}$ histogram skewed towards 'Cornell 503', emphasizes heterotic and dominance genetic action for heat tolerance. This indicates selection for heat tolerance should be undertaken in advanced inbred lines in order to avoid the confounding influence of these genetic effects.

Generation means analysis for pod number required a sixparameter model that includes significant nonallelic interaction terms to explain differences among phenotypes in the six generations (Table 3). Significant interaction terms for pod number are likely the result of epistatic interaction of the abscission gene with genes conditioning pod number. Moreover, pod number was highly correlated with abscission score $(P \leq 0.0001)$. The action on the abscission gene is also apparent from the large goodnessof-fit values for the $\mathrm{BC}_{1} \mathrm{P}_{1}$ and $\mathrm{F}_{2}$ generations (Table 4), as segregating individuals with high rates of abscission increased the number of 

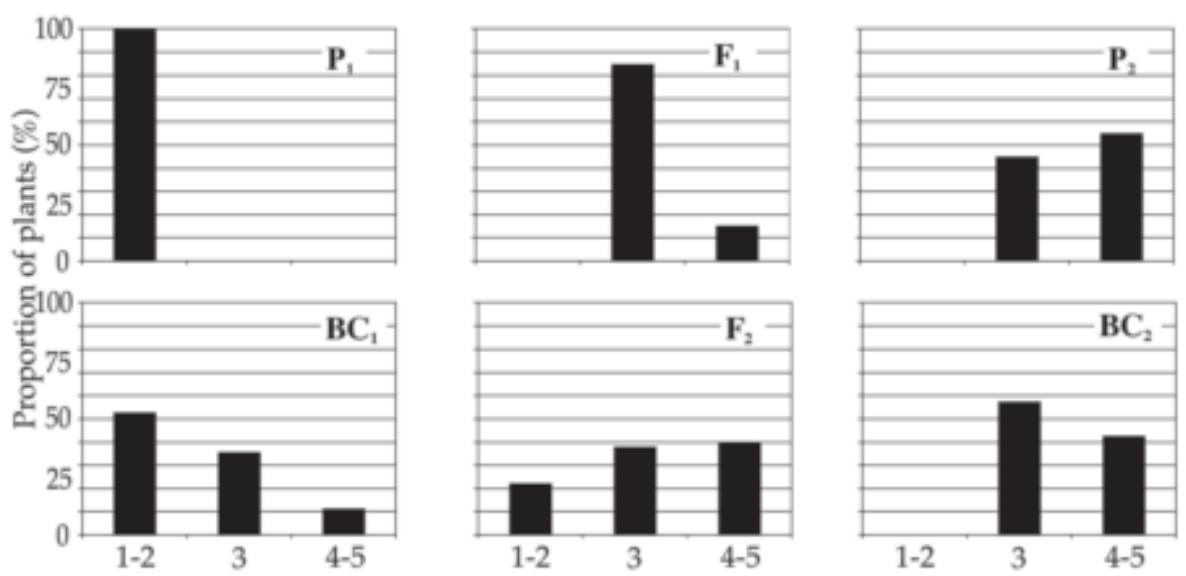

Abscission score
Broad-sense heritability for abscission score was high (0.79), as to be expected of a simply inherited major gene. Pod number broad-sense heritability was also high (0.74), but may be overestimated due to epistatic interaction of this trait with the potential gene controlling abscission. Additionally, this interaction resulted in low variance for pod number for 'Majestic', which lowered estimates of environmental variance for this trait. Heritability estimates are generally low in common bean and other grain legumes for various traits related to heat tolerance (Dickson, 1993; Marfo and Hall, 1992). Heritability was negative for seeds per pod, because variance for this yield component was higher for 'Majestic' than the $F_{2}$ (see the third paragraph of this section). The presence of dominant and epistatic gene action in this cross violated assumptions for calculation of narrow-sense heritability.

\section{Discussion}

In this study, dominance genetic effects were larger than additive, in agreement with prior work on reproductive heat tolerance in common bean. Bouwkamp and Summers (1982), and Dickson and Petzoldt (1989) also determined that dominant gene action is important in controlling pod set under heat stress. However, these two early studies did not emphasize high night temperatures, with temperature regimes of $43{ }^{\circ} \mathrm{C} / 25{ }^{\circ} \mathrm{C}$ in the former, and $35^{\circ} \mathrm{C} / 22^{\circ} \mathrm{C}$ in the latter. This is important as night temperatures, generally $\geq 27^{\circ} \mathrm{C}$, cause critical yield loss in common bean (Gross and Kigel, 1994; Konsens et al., 1991; Porch and Jahn, 2001; Rainey and Griffiths, 2005a; Suzuki et al., 2001). The current authors found evidence for non-additive genetic effects for reproductive heat tolerance in a diallel analysis of ten snap bean breeding lines and cultivars as indicated by significant specific combining ability (SCA) effects (Rainey and Griffiths,

zUnder high-temperature stress $\left(32{ }^{\circ} \mathrm{C}\right.$ day/28 ${ }^{\circ} \mathrm{C}$ night $)$ in a controlled environment, abscission of a large percentage of total reproductive organs (RO) corresponds to a score of " 1 " or " 2 ," abscission of a moderate percentage of RO corresponds to " 3 ," and abscission of a low percentage of RO corresponds to a rating of " 4 " or " 5 ." $\mathrm{P}_{1}=$ 'Majestic' (heat sensitive), $\mathrm{P}_{2}=$ 'Cornell 503' (heat tolerant).

yPercentage of individuals of each generation observed to have either high abscission, or low to moderate abscission.

individuals in these generations with low pod number. Similarly, this effect may also have resulted in significant correlation between seed number and both pod number and abscission score. Despite this correlation, a simple additive-dominance model was sufficient to explain variation among generations for seeds per pod (Table 3 ). Negative values for $[d]$ and $[j]$ are the result of designating the low parent (heat sensitive) as $\mathrm{P}_{1}$ in calculations. A negative value for the additive $\times$ additive epistatic interaction parameter, $[i]$, for pod number indicated alleles responsible for pod number were in dispersive form, meaning both parents contributed positive alleles influencing pod number under heat stress during reproductive development (Mather and Jinks, 1982). Parameter estimates were all significant for both pod number and seeds per pod (Table 3 ). For both pod number and seeds per pod dominance components of genetic variation $([h],[l])$ were greater in magnitude than additive $([d],[i])$ components. 2005b). Observing dry bean crosses under high-temperature field conditions, Shonnard and Gepts (1994) found additive genetic effects to be most important for tolerance to bud abortion, with dominance present in certain crosses, and negative additive $x$ additive epistatic effects influencing percent pod fill. A negative additive $\times$ additive epistatic effect, $[i]$, was significant in the current study for pod number $[i]$, and indicates both parents contributed positive alleles influencing pod number under heat stress during reproductive development. This observation suggests alleles and genes conditioning heat tolerance may exist in other heat-sensitive common beans, but their action is masked by genes such as the one potentially controlling abscission observed in this study. This result emphasizes that although abscission of RO under heat stress may be under major gene control in this cross, the number of pods set under heat stress is a multiple-gene trait with quantitative inheritance. 
A

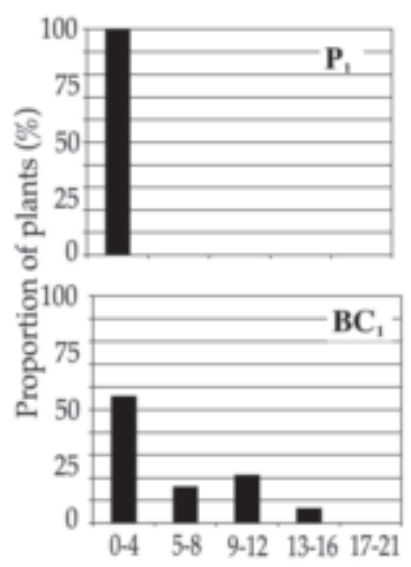

B

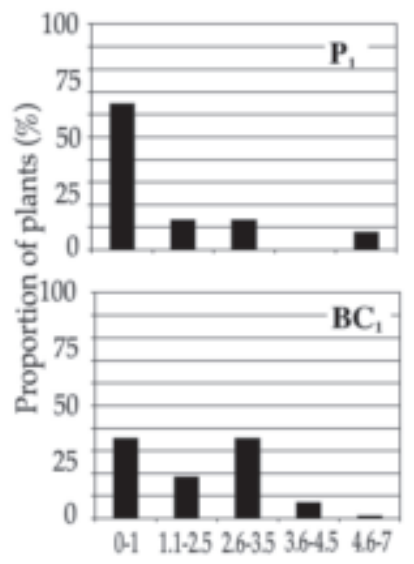

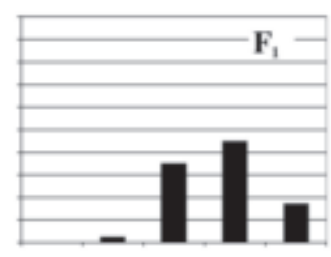

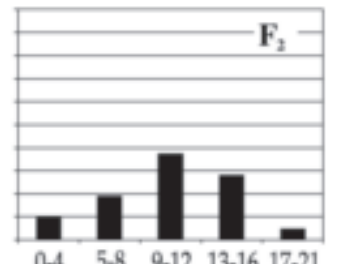

$\begin{array}{lllll}0-4 & 5-8 & 9-12 & 13-16 & 17-21\end{array}$ Pods (no.)
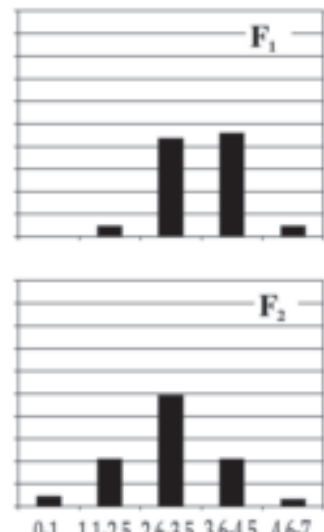

(0-1 $\quad 1.1-2.526-3.53 .645 \quad 46-7$

Seeds (no./pod)
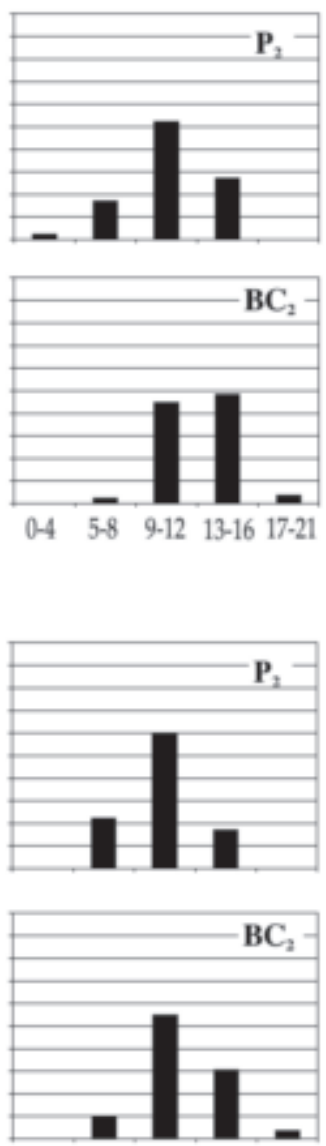

0-1 $\quad 1.1-2.5 \quad 2.6-3.53 .6-45 \quad 4.6-7$

Fig. 2. Histograms of (A) pod number and (B) seeds per pod for six generations from the cross 'Majestic' $\times$ 'Cornell 503' when plants were grown under high-temperature stress $\left(32^{\circ} \mathrm{C}\right.$ day $/ 28^{\circ} \mathrm{C}$ night $)$ in a controlled environment. $\mathrm{P}_{1}=$ 'Majestic' (heat sensitive), $\mathrm{P}_{2}=$ 'Cornell 503' (heat tolerant).

Table 3. Parameter estimates of gene effects $( \pm \mathrm{SE})$ from the joint scaling test for the traits pod number and seeds per pod for six generations from the cross 'Majestic' $\times$ 'Cornell 503' when plants were grown under high-temperature stress (32 ${ }^{\circ} \mathrm{C}$ day $/ 28^{\circ} \mathrm{C}$ night) in a controlled environment.

\begin{tabular}{lcccr}
\hline & \multicolumn{2}{c}{ Pods (no.) } & \multicolumn{2}{c}{ Seeds (no./pod) } \\
\hline$[\mathrm{m}]^{\mathrm{z}}$ & $11.9^{* * *}$ & \pm 1.1 & $2.1^{* * * *}$ & \pm 0.1 \\
{$[d]^{\mathrm{y}}$} & $-5.0^{* * *}$ & \pm 0.2 & $-0.9^{* * *}$ & \pm 0.1 \\
{$[h]$} & $-7.8^{* *}$ & \pm 2.8 & $1.5^{* * *}$ & \pm 0.2 \\
{$[i]^{\mathrm{x}}$} & $-6.3^{* * *}$ & \pm 1.1 & --- & \\
{$[j]^{\mathrm{y}}$} & $-5.7^{* * *}$ & \pm 0.8 & --- & \\
{$[l]$} & $9.1^{* * *}$ & \pm 1.9 & --- &
\end{tabular}

$\mathrm{z}[\mathrm{m}]=$ estimated mean, $[d]=$ additive, $[h]=$ dominance, $[i]=$ additive $\times$ additive, $[j]=$ additive $\times$ dominance, $[l]=$ dominance $\times$ dominance gene effects.

yNegative values for $[d]$ and $[j]$ are a result of using the low parent (i.e., heat sensitive) as $\mathrm{P}_{1}$ in calculations.

xA negative value for $[i]$ indicates positive alleles conditioning pod number are dispersed between the parents.

**,***Deviation from zero is significant at $P<0.001$ or 0.0001 levels, respectively, according to one-sample $t$ tests.
Heterosis for pod number and seeds per pod was observed in the current study. Dispersal of alleles in parents and unidirectional dominance are thought to be responsible for heterosis (Pooni and Treharne, 1994), and both types of genetic action were significant in this study. Evidence that both parents contributed positive alleles influencing pod number under heat stress may explain the observation of significant high-parent heterosis, as positive alleles, genes, or both, from 'Majestic' increased pod number in the $\mathrm{F}_{1}, \mathrm{~F}_{2}$, and $\mathrm{BC}_{1} \mathrm{P}_{2}$ over 'Cornell 503'. Heterosis in some crosses for percent pod fill was also observed by Shonnard and Gepts (1994). Dickson (1993) noted that the $\mathrm{F}_{1}$ between heat-tolerant and heat-sensitive lines was more heat tolerant than parents and $\mathrm{F}_{2}$ progenies in two studies. Heterosis for yield and yield components was significant in numerous studies of dry bean (Evans, 1970; Foolad and Bassiri, 1983; Nienhuis and Singh, 1986).

Abscission of reproductive organs is the most significant reaction to heat stress of grain legumes and other crops, including Brassica L. species (Morrison and Stewart, 2002), pepper (Erickson and Markhart, 2002), and tomato (Lycopersicon esculentum Mill.; Sato et al., 2001). Based on evidence from three segregating generations, the current study found abscission of reproductive organs due to heat stress in the sensitive parent, 'Majestic', and a subset of its progeny, was controlled by a single recessive gene. $\mathrm{F}_{3}$ progeny tests of lines from individual $\mathrm{F}_{2}$ plants are needed to confirm this observation. Major gene control of this critical reaction to high-temperature stress has not been previously reported in common bean, or other grain legumes. This finding is potentially useful for development of molecular markers for marker-assisted selection (Forster et al., 2000), and further genetic and physiological characterization of reproductive heat stress. If confirmed, the gene could potentially be fine-mapped to its chromosomal location on the common bean linkage map (Gepts, 1999). Cloning and sequencing this gene might identify its function, which could provide insight into the possible mechanisms contributing to heat sensitivity in common bean and other grain legumes (Tang et al., 2004). Physiological characterization of dwarfing genes in cereals led to the development of physiological screening criteria for yield, and aided breeders in developing strategies for deployment of genes in different environments (Blum and Nguyen, 2004).

That the heat-sensitive reaction of 'Majestic' is overcome by a dominant allele present in 'Cornell 503' is important from a breeding perspective. Genetics of high temperature tolerance are better characterized in cowpea than common bean, and responses of the two species are thought to be similar (Hall, 2004). In cowpea, the action of a single recessive gene and some minor genes has been shown to enhance the ability of plants to set pods under heat stress. This tolerance can be fixed by selection in the $\mathrm{F}_{2}$, although heritability is low and requires multiple generations of 
Table 4. A joint scaling test ${ }^{\mathrm{z}}$ of the observed and expected means for six generations from the cross 'Majestic' $\times$ 'Cornell 503 ' for the traits pod number and seeds per pod when the plants were grown under high-temperature stress $\left(32^{\circ} \mathrm{C}\right.$ day/28 ${ }^{\circ} \mathrm{C}$ night $)$ in a controlled environment.

\begin{tabular}{|c|c|c|c|c|c|c|c|c|}
\hline \multirow[b]{2}{*}{ Generation } & \multicolumn{4}{|c|}{ Pods (no.) } & \multicolumn{4}{|c|}{ Seeds (no./pod) } \\
\hline & Observed & Expected & $\begin{array}{c}\text { Squared } \\
\text { deviation }\end{array}$ & $\begin{array}{c}\text { Goodness- } \\
\text { of-fit }\end{array}$ & Observed & Expected & $\begin{array}{c}\text { Squared } \\
\text { deviation }\end{array}$ & $\begin{array}{c}\text { Goodness- } \\
\text { of-fit }\end{array}$ \\
\hline$\overline{\mathrm{P}_{1} \text { ('Majestic') }}$ & 0.57 & 0.33 & 0.058 & 2.26 & 1.17 & 1.26 & 0.009 & 0.091 \\
\hline $\mathrm{P}_{2}$ ('Cornell 503') & 10.65 & 11.79 & 1.30 & 8.55 & 2.92 & 3.01 & 0.009 & 0.764 \\
\hline $\mathrm{F}_{1}$ & 13.33 & 12.96 & 0.138 & 0.71 & 3.55 & 3.64 & 0.009 & 0.858 \\
\hline $\mathrm{F}_{2}$ & 10.35 & 9.51 & 0.707 & 14.91 & 2.97 & 2.89 & 0.006 & 2.572 \\
\hline $\mathrm{BC}_{1} \mathrm{P}_{1}$ & 4.81 & 6.64 & 3.350 & 50.62 & 1.97 & 2.45 & 0.233 & 6.889 \\
\hline \multirow[t]{2}{*}{$\mathrm{BC}_{1} \mathrm{P}_{2}$} & 12.72 & 12.37 & 0.120 & 2.12 & 3.33 & 3.33 & 0.000 & 0.001 \\
\hline & \multicolumn{3}{|c|}{ Sum of contributions $=$} & 79.153 & \multicolumn{3}{|c|}{ Sum of contributions = } & $11.175^{*}$ \\
\hline
\end{tabular}

zThe joint scaling test of Cavalli (1952) tests the adequacy of the simple additive/dominance model.

*The observed generation means are not significantly different from the expected generation means under the simple/additive dominance model at $P \leq 0.01$.

family selection to stabilize high pod set (Marfo and Hall, 1992). Considering such breeding accomplishments in cowpea, results reported here provide evidence that improvement of heat tolerance in common bean may involve genes with major effects.

\section{Literature Cited}

Ahmed, F.E., A.E. Hall, and M.A. Madore. 1993. Interactive effects of high temperature and elevated carbon dioxide concentration on cowpea (Vigna unguiculata (L.) Walp.). Plant Cell Environ. 16:835-842.

Allard, R.W. 1960. Principles of plant breeding. Wiley, New York.

Aloni, B., L. Karni, Z. Zaidman, and A.A. Schaffer. 1996. Changes of carbohydrates in pepper (Capsicum annuиm L.) flowers in relation to their abscission under different shading regimes. Ann. Bot. 78:163-168.

Blum, A. and T. Nguyen. 2004. Physiology and biotechnology integration for plant breeding: Epilogue, p. 611-618. In: H.T. Nguyen and A. Blum (eds.). Physiology and biotechnology integration for plant breeding. Marcel Dekker, New York.

Boodley, J.W. and R. Sheldrake, Jr. 1972. Cornell peat-lite mixes for commercial plant growing. Cornell Info. Bul. 43:1-8.

Bouwkamp, J.C. and W.L. Summers. 1982. Inheritance of resistance to temperature-drought stress in snap bean. J. Hered. 73:385-386.

Cavalli, L.L. 1952. An analysis of linkage in quantitative inheritance, p. 35-144. In: E.C.R. Reeve and C.H. Waddington (eds.). Quantitative inheritance. HMSO, London.

Craufurd, P.Q., M. Bojang, T.R. Wheeler, and R.J. Summerfield. 1998. Heat tolerance in cowpea: Effect of timing and duration of heat stress. Ann. Appl. Biol. 133:257-267.

Cunha, C., T. Hintz, and P.D. Griffiths. 2004. Genetic diversity of snap bean cultivars determined using randomly amplified polymorphic DNA (RAPD) markers. HortScience. 39:481-484.

Currence, T.M. 1931. A new pod color in snap beans. J. Hered. 22:21-23.

Dickson, M.H. 1993. Breeding for heat tolerance in green beans and broccoli, p. 296-320. In: C.G. Kuo (ed.). Adaptation of food crops to temperature and water stress. Asian Veg. Res. Dev. Center Pub. 93-410.

Dickson, M. H. and R. Petzoldt. 1989. Heat tolerance and pod set in green beans. J. Amer. Soc. Hort. Sci. 114:833-836.

Erickson, A.N. and A.H. Markhart. 2002. Flower developmental stage and organ sensitivity of bell pepper (Capsicum аппиит L.) to elevated temperature. Plant Cell Environ. 25:123-130.

Evans, A. 1970. Heterosis for yield in Phaseolus vulgaris crosses. Annu. Rpt. Bean Improvement Coop. 13:52-54.

Fehr, W.R. 1987. Heterosis, p. 115-119. In: W.R. Fehr (ed.) Principles of cultivar development: Volume 1: Theory and technique. Macmillan, New York.

Foolad, M.R. and R.A. Bassiri. 1983. Estimates of combining ability, reciprocal effects, and heterosis for yield and yield components in a common bean diallel cross. J. Agr. Sci. 100:103-180.

Forster, B.P., R.P. Ellis, W.T.B. Thomas, A.C. Newton, R. Tuberosa, D. This, R.A. El-Enin, M.H. Bahri, and M. Ben Salem. 2000. The development and application of molecular markers for abiotic stress tolerance in barley. J. Expt. Bot. 51:19-27.

Gepts, P. 1999. Development of an integrated linkage map, p. 53-91. In: S.P. Singh (ed.). Common bean improvement in the twenty-first century. Kluwer, Dordrecht, The Netherlands.

Gross, Y. and J. Kigel. 1994. Differential sensitivity to high temperature of stages in the reproductive development of common bean (Phaseolus vulgaris L.). Field Crops Res. 36:201-212.

Guilioni, L., J. Wery, and F. Tardieu. 1997. Heat stress-induced abortion of buds and flowers in pea: is sensitivity linked to organ age or to relations between reproductive organs? Ann. Bot. 80:159-168.

Haley, S.D., P.N. Miklas, L. Afanador, and J.D. Kelly. 1994. Random amplified polymorphic DNA (RAPD) marker variability between and within gene pools of common bean. J. Amer. Soc. Hort. Sci. 119:122-125.

Hall, A.E. 2004. Comparative ecophysiology of cowpea, common bean, and peanut, p. 271-326. In: H.T. Nguyen and A. Blum (eds.). Physiology and biotechnology integration for plant breeding. Marcel Dekker, New York.

Konsens, I., M. Ofir, and J. Kigel. 1991. The effect of temperature on the production and abscission of flowers and pods in snap bean (Phaseolus vulgaris L.). Ann. Bot. 67:391-399.

Kuiper,D. 1993. Sink strength: established and regulated by plant growth regulators. Plant Cell Environ. 16:1025-1026.

Lamprecht, H. 1947. The inheritance of the slender-type of Phaseolus vulgaris and some other results. Agri Hortique Genetica 5:72-84.

Lebon, G., E. Duchêne, O. Brun, C. Magné, and C. Clément. 2004. Flower abscission and inflorescence carbohydrates in sensitive and non-sensitive cultivars of grapevine. Sexual Plant Reproduction. 17:71-79.

Li, P.H. and N. Udomprasert. 1993. Improving crop performance of Phaseolus vulgaris in high-temperature environments by heat acclimation potential, p. 301-315. In: C.G. Kuo (ed.). Adaptation of food crops to temperature and water stress. Asian Veg. Res. Dev. Center Pub. no. 93-410.

Marcelis, L.F.M., E. Heuvelink, L.R. Baan Hofman-Eijer, J. Den Bakker, and L.B. Xue. 2004. Flower and friut abortion in relation to source and sink strength. J. Expt. Bot. 55:2261-2268.

Marfo, K.O. and A.E. Hall. 1992 Inheritance of heat tolerance during pod set in cowpea. Crop Sci. 32:912-918.

Mather, K. and J.L. Jinks. 1982. Biometrical genetics. Cornell Univ. Press, Ithaca, N.Y.

Monterroso, V.A. and H.C. Wien. 1990. Flower and pod abscission due to heat stress in beans. J. Amer. Soc. Hort. Sci. 115:631-634.

Morrison, M.J. and D.W. Stewart. 2002. Heat stress during flowering in summer brassica. Crop Sci. 42:797-803.

Mutters, R.G. and A.E. Hall. 1992. Reproductive responses of cow- 
pea to high temperature during different night periods. Crop Sci. 32:202-206

Myers, J.R. and J.R. Baggett. 1999. Improvement of snap beans, p. 289-330. In: S.P. Singh (ed.). Common bean improvement in the twenty-first century. Kluwer, Dordrecht, The Netherlands.

Ng., T.J. 1990. Generations means analysis by microcomputer. HortScience 25:363.

Nienhius, J. and S.P. Singh. 1986. Combining ability analysis and relationships among yield, yield components, and architectural traits in dry bean. Crop Sci. 26:21-27.

Ofir, M., Y. Gross, F. Bangerth, and J. Kigel. 1993. High temperature effects on pod and seed production as related to hormone levels and abscission of reproductive structures on common bean (Phaseolus vulgaris L.). Scientia Hort. 55:201-211.

Pooni, H.S. and A.J. Treharne. 1994. The role of epistasis and background genotype in the expression of heterosis. Heredity 72:628-635.

Porch, T.G. 2001. Genetics and applications of heat tolerance in common bean. PhD Diss. P673, Cornell Univ., Ithaca, N.Y.

Porch, T.G. and M. Jahn. 2001. Effects of high-temperature stress on microsporogenesis in heat-sensitive and heat-tolerant genotypes of Phaseolus vulgaris. Plant Cell Environ. 24:723-731.

Prasad, P.V., P.Q. Craufurd, and R.J. Summerfield. 1999. Sensitivity of peanut to timing of heat stress during reproductive development. Crop Sci. 39:1352-1357.

Rainey, K.M. and P.D. Griffiths. 2005a. Differential response of com- mon bean genotypes to high temperature. J. Amer. Soc. Hort. Sci. 130:18-23.

Rainey, K.M. and P.D. Griffiths. 2005b. Diallel analysis of yield components of snap beans exposed to two temperature stress environments. Euphytica 142:43-53.

Sato, S., M.M. Peet, and R.G. Gardener. 2001. Formation of parthenocarpic fruit, undeveloped flowers and aborted flowers in tomato under moderately elevated temperatures. Scientia Hort. 90:243-254.

SAS Institute. 1997. SAS user's guide. SAS Inst., Cary, N.C.

Shonnard, G.C. and P. Gepts. 1994. Genetics of heat tolerance during reproductive development in common bean. Crop Sci. 34:1168-1175.

Silbernagel, M.J. 1986. Snap bean breeding, p. 243-282. In: M.J. Bassett (ed.). Breeding vegetable crops. AVI, Westport, Conn.

Skroch, P.W. and J. Nienhuis. 1995. Qualitative and quantitative characterization of RAPD variation among snap bean (Phaseolus vulgaris L.) genotypes. Theor. Appl. Genet. 91:1078-1085.

Suzuki, K., T. Tsukaguchi, H. Takeda, and Y. Egawa. 2001. Decrease of pollen stainability of green bean at high temperatures and relationship to heat tolerance. J. Amer. Soc. Hort. Sci. 126:571-574.

Tang, D., H. Qian, S. Yu, Y. Cao, Z. Liao, L. Zhao, X. Sun, D. Huang, and K. Tang. 2004. cDNA cloning and characterization of a new stress-responsive gene BoRS1 from Brassica oleracea var. acephala. Physiol. Plant. 121:578-585.

Vierling, E. 1991. The roles of heat-shock proteins in plants. Annu. Rev. Plant Physiol. Plant Mol. Biol. 42:579-620. 